\title{
Effect of Previous Crop on Susceptibility of Flax to Rhizoctonia solani Hussein, E. M. ${ }^{1}$; A. A. Aly ${ }^{1}$; Ola G. H. EL-Hawary ${ }^{1}$; A. A. Mosa $^{2}$; M. H. Mostafa ${ }^{2}$ and Amal A. Asran ${ }^{1}$ ${ }^{1}$ Plant Pathology Research Institute, Agricultural Research Center, Giza, Egypt. \\ ${ }^{2}$ Department of Plant Pathology,Faculty of Agriculture,Ain Shams Univ,Cairo, Egypt.
}

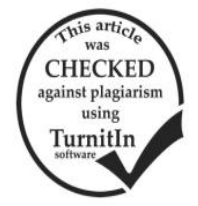

\section{ABSTRACT}

Effect of Rhizoctonia solani AG group,previous crop, flax cultivar,and their interactions on the incidence of flax seedling blight were studied under greenhouse conditions in autoclaved soil.All the main effects of AG group,previous crop,and cultivar were highly significant sources of variation in survival. Of the first order interactions, AG group x previous crop was the only significant source of variation. The second order interaction of AG group x previous crop x cultivar was a nonsignificant source of variation. All the previous crops significantly reduced survival within each AG; however,the magnitude of reduction varied from one AG to another. Thus, within AG-2,corn,rice, and cotton reduced survival by $32.42,16.69$, and $6.82 \%$ respectively, while withinAG- 4 , con, rice, and cotton reduced survival by $4.68,11.55$, and $11.55 \%$, respectively.

\section{INTRODUCTION}

Rhizoctonia solani Kühn(teleomorph:Thanateophorus cucumerise(Frank)Donk) is one of the more primitive Basidomycetes.R.solani exists in its vegetative form in nearly all agricultural soils. In this non-spore-producing phase, the fungus lives saprophytically on dead plant remains, but it can become vigorously parasitic when roots or other parts of a susceptible host penetrate the infested zone(Watkins, 1981).

Current classification of R.solani is based largely on grouping of isolates into anastomosis groups (AGs). Anastomosis,or the fusion of hyphae between different individuals, may result in the sharing of genetic material without sexual reproduction, but it also serves to isolate individuals from other members of the same species that do not share the alleles for somatic compatability (Agrios,2005).

R.solani attacks flax at early stage of development, destroying the root and causing thinning or in severe infection, death the of seedlings(Krylova,1981). R.solani also causes root rot symptoms, which appear in plants after flowering stage (Hartman,1996).

Susceptibility of flax to R.solani is markedly affected by previous crop and such an effect is documented in the literature. For example, Ligocka et al.(2002)indicated that crop rotation was responsible for significant differences in the quantitative and qualitative composition of microorganisms population. The flax infection index values for the cultivation in monoculture and a six-field crop rotation(flax, rye, faba bean ,winter triticale, potato, and oats)showed an unfavorable effect of monoculture on the fibrous flax growth especially over emergence. It was observed that over emergence the crop root infection was greater than over flowering, both in monoculture and in crop rotation. The crop rotation showed a high decrease in the occurrence of the root pathogens by $16.82 \%$ over emergence and by $20.17 \%$ over flowering. Clear-cut changes were observed for both flax development phases in monoculture, which was considerably responsible for the accumulation of pathogenic fungi, including Rhizoctonia but Fusarium mainly. As for other pathogenic fungi ,it was noted that, irrespective of the crop rotation, their greater population was recorded over flowering ..
Flax does well after legume crops, but Rhizoctonia disease may be a problem. Flax does not do well after potatoes or sugar beets as the soil may be too loose and Rhizoctonia disease could also be a problem(Anonymous,2006).

However, due to the lack of studies, the effects of previous crop on susceptibility of flax to R.solani under Egyptian conditions are unclear. Therefore, the objective of the present study was to evaluate the effects of some previous crops on susceptibility of flax to R.solani. Rice ,corn,and cotton were chosen as previous crops because they are the most common summer crops, which are cultivated before flax,and representative isolates of AG-2 and AG-4 were used for soil infestation because all isolates of R.solani from flax roots belong to these AGs(ELHawary et al.,2008)

\section{MATERIALS AND METHODS}

\section{Production of R.solani inoculum used in soil infestation}

Isolates of R.solani used in the present study for soil infestation were obtained from the fungal collection of Cotton and Fiber Crops Diseases Rresearch Section, Plant Pathology Research Institute, Agric. Res. Cent., Giza, Egypt. These isolates were originally isolated from flax roots.

Substrate for growth of the isolates was prepared in $500-\mathrm{ml}$ glass bottles, each bottle contained $50 \mathrm{~g}$ of barley grains and $40 \mathrm{ml}$ of tap water. Contents . of each bottle were autoclaved for 30 minutes. Isolate inoculums, taken from one -week old culture on PDA, was aseptically into the bottle and allowed to colonize barley for three weeks . The mixture of barley and R.solani was used for soil infestation.

Effects of some previous crops on susceptibility of flax to R.solani.

Autoclaved clay loam soil was artificially infested at a rate of $1 \mathrm{~g} / \mathrm{kg}$ of soil,and dispensed in 30-cm-diameter clay pots. In the last week of March 2006 , three summer (pervious) crops were planted in the infested pots. The tested summer crops were rice (Oryza sativa L.,cv. Sakha101) Corn (Zea mays L.,cv.SC.10), and Cotton (Gossypium barbadense L.,cv.Giza89).In the control treatments (infested and non-infested), pots were left without planting, there were three pots for each treatment. 
Pots were randomly distributed outdoors. In the end of October, summer crops were uprooted and all pots were planted with five flax cultivars (Sakha1, Sakha2, Marlin, Electra, and Elona) at a rate of 50 seeds per pot. Preemergence damping- off was recored 20 day after sowing, while postemergence damping- off and suevival were recorded two months after sowing. The temperature regime during flax- growing period ranged from $16 \pm 2$ to $22 \pm 2.5 \mathrm{oC}$.

\section{Statistical analysis of the data.}

The present study was carried out in a randomized complete block design of three replicates. Percentage data were transformed into arcsine angles to produce approximately constant variance before carrying out the analysis of variance (ANOVA).Least significant difference (LSD) was used to compare between treatment means. ANOVA was carried out by MSTAT-C statistical package

\section{RESULTS AND DISCUSSION}

All the main effects of A Ggroup, previous crop, and cultivar were highly significant sources of variations in survival. Of the first order interactions, AG group $\mathrm{x}$ previous crop was the only significant source of variation. The second order interaction was a non significant source of variation (Table1).

Of the significant sources of variation, cultivar was the most important one, while AGgroup x previous crop interaction was the least important one (Table2).

Table 1. Analysis of variance of the effect of AGgroup,previous crop, flax cultivar and their interactions on survival of flax seedlings under greenhouse conditions.

\begin{tabular}{lcccc}
\hline Source of variation $^{\mathbf{a}}$ & $\mathbf{D . F}^{\mathbf{b}}$ & $\mathbf{M . S}^{\mathbf{c}}$ & $\mathbf{F . v a l u e}$ & $\mathbf{P}^{\mathbf{c}} \mathbf{F}^{\mathbf{d}}$ \\
Replication $^{\mathbf{a}}$ & 2 & 0.689 & 0.0555 & 0.0000 \\
AG group (A) & 1 & 1919.561 & 154.4217 & 0.0000 \\
Previous crop(B) & 3 & 496.678 & 40.0185 & 0.0000 \\
AxB & 3 & 382.810 & 30.8439 & 0.0000 \\
Cultivars (C) & 4 & 707.043 & 56.9681 & 0.0000 \\
AxC & 4 & 19.061 & 1.5358 & 0.3610 \\
BxC & 12 & 13.830 & 1.1143 & 0.3020 \\
AxBxC & 12 & 14.826 & 1.1946 & \\
Error & 78 & 12.411 & & \\
\hline
\end{tabular}

${ }^{a}$ Replication is random, while each of cultivar, previous crop, and AG group is fixed.

${ }^{\mathrm{b}} \mathrm{D} . \mathrm{F}=$ Degrees of freedom.

${ }^{\mathrm{c}}$ M.s.= Mean of squars.

${ }^{\mathrm{d}} \mathbf{P}>\mathbf{F}=$ Probability of greater $\mathbf{F}$. value.

Table 2. Relative contributions of anastomosis group, previous crop, flax cultivar, and their interactions to variation in survival of flax seedlings under greenhouse conditions.

\begin{tabular}{lc}
\hline Source of variation & Relative contribution to variation in survival $^{\mathbf{a}}$ \\
\hline Anastomosis group(A) & 24.59 \\
Previous crop (B) & 19.08 \\
Ax B & 14.71 \\
Cultivar( C) & 36.22 \\
Ax C & 0.98 \\
B x C & 2.13 \\
A x B x C & 2.28 \\
\hline
\end{tabular}

a calculated as percentage of sum of squares of the explained (model) variation.

Due to the significant interaction of AGgroup $\mathrm{x}$ previous crop, an interaction LSD was calculated to compare between previous crops within each AG. These comparisons showed that all the previous crops significantly reduced survival within each AG; however, the magnitude of reduction varied from one $A G$ to another. Thus, within AG-2,corn, rice, and cotton reduced survival by $32.42,15.69$, and $6.82 \%$, respectively, while within G4 , corn, rice, and cotton reduced survival by $4.68,11.55$, and $11.55 \%$, respectively (Table3).

The comparisons among the general means of cultivars revealed that the introductions were more resistant to infection than the local cultivars Sakh1 and sakh2 regardles of the AGgroup and the previous crop.
In general, previous crop can induce disease by allowing inoculums levels to increase in the absence of the host, directly activating the pathogen by producing stimulating compounds, suppressing specific antagonists that inhibit the pathogen, or by decreasing general microbial populations that compete with the pathogen (Van Bruggen et al., 1996). It seems reasonable to assume that survival of R.solani in root debris of the previous crops and its subsequent increases in inoculums density may contribute to the observed increases in disease incidence. Since the present study was carried out in autoclaved soil, it is unlikely that soil microbial populations were implicated in the observed increases in disease incidence. Further research is needed to elucidate the reason(s) of such increases. 
Table 3. Effects of AG group, previous crop, flax cultivar and their interactions on survival of flax seedlings under greenhouse conditions.

\begin{tabular}{|c|c|c|c|c|c|c|c|c|c|c|c|c|c|}
\hline \multirow[b]{2}{*}{ AG group } & \multicolumn{13}{|c|}{ Cultivar } \\
\hline & $\begin{array}{c}\text { Previous } \\
\text { crop }\end{array}$ & $\%^{a}$ & $\begin{array}{c}\text { Sakha1 } \\
\text { Arc sine }\end{array}$ & $\%$ & $\begin{array}{c}\text { Sakha1 } \\
\text { Arc sine } \\
\end{array}$ & $\%$ & $\begin{array}{c}\text { Marlin } \\
\text { Arc sine }\end{array}$ & $\%$ & $\begin{array}{c}\text { Electra } \\
\text { Arc sine } \\
\end{array}$ & $\%$ & $\begin{array}{c}\text { Elona } \\
\text { Arc sine }\end{array}$ & $\%$ & $\begin{array}{c}\text { Mean } \\
\text { Arc sine }\end{array}$ \\
\hline \multirow[t]{5}{*}{ AG2-2 } & corn & 55.33 & $(48.07)$ & 32.00 & $(34.45)$ & 70.00 & $(56.85)$ & 46.67 & $(43.11)$ & 60.00 & $(50.77)$ & 52.80 & $(46.65)$ \\
\hline & Rice & 61.33 & (51.56) & 53.33 & (46.90) & 76.00 & (60.70) & 72.67 & (58.56) & 66.00 & (54.33) & 65.87 & $(54.41)$ \\
\hline & Cotton & 67.33 & (55.15) & 64.00 & (53.13) & 82.00 & (64.92) & 78.67 & $(62.50)$ & 72.00 & $(58.09)$ & 72.80 & $(58.76)$ \\
\hline & Control & 74.00 & (59.38) & 68.66 & (55.96) & 88.00 & (69.77) & 83.33 & $(65.91)$ & 76.67 & (61.15) & 78.13 & $(62.44)$ \\
\hline & Mean & 64.49 & $(53.54)$ & 54.49 & $(47.61)$ & 79.00 & $(63.06)$ & 70.34 & $(57.52)$ & 68.67 & $(56.09)$ & 67.40 & $(55.57)$ \\
\hline \multirow[t]{6}{*}{$\overline{\mathrm{AG}-4}$} & corn & 76.00 & $(60.72)$ & 72.67 & $(58.54)$ & 90.67 & $(72.47)$ & 87.33 & $(69.21)$ & 80.67 & $(63.93)$ & 81.47 & $(64.97)$ \\
\hline & Rice & 70.67 & $(57.30)$ & 66.67 & (54.81) & 84.67 & (67.07) & 81.33 & $(64.43)$ & 74.67 & (59.79) & 75.60 & $(60.68)$ \\
\hline & Cotton & 70.67 & (57.27) & 66.67 & (54.77) & 84.67 & (67.02) & 81.33 & $(64.43)$ & 74.67 & (59.78) & 75.60 & (60.66) \\
\hline & Control & 80.00 & $(63.58)$ & 76.67 & $(61.27)$ & 92.67 & (74.32) & 90.67 & $(72.29)$ & 87.33 & (68.13) & 85.47 & $(67.92)$ \\
\hline & Mean & 74.34 & (59.72) & 70.67 & $(57.35)$ & 88.17 & $(70.22)$ & 85.17 & (67.59) & 79.34 & (62.91) & 79.54 & (63.56) \\
\hline & Overalmean & 69.41 & (56.63) & 62.58 & $(52.48)$ & 83.59 & (66.64) & 77.75 & (62.56) & 74.00 & (59.49) & 73.47 & (59.57) \\
\hline \multirow[t]{5}{*}{ Mean of } & Previous crop & & & & & & & & & & & & \\
\hline & corn & 67.14 & $(55.81)$ & & & & & & & & & & \\
\hline & Rice & 70.74 & (57.55) & & & & & & & & & & \\
\hline & Cotton & 74.20 & (59.71) & & & & & & & & & & \\
\hline & Control & 81.80 & $(65.18)$ & & & & & & & & & & \\
\hline
\end{tabular}

a percentage data were transformed into arc sine angles before carrying out ANOVA to produce constant variance.

LSD ( transformed) data for AG x previous crop interaction= 2.56 ( p (0.05 >or 3.40$)$ p. $(0.01>$

LSD for Cultivar $=2.03) \mathrm{p}(0.05>0$ or 2.69$) \mathrm{p} .(0.01>$

\section{REFERENCES}

Agrios, G.N.2005." Plant Pathology",5 $5^{\text {th }}$ Ed. Elsevie Academic Press, Sa Diego,California,384p.

Anonymous. 2006. Grwing Flax: Production, Management, and Diagnostic Guide.4th Ed.Flax Council of Canada and Saskatchewam. Flax Commission. Available on line http:// Flaxcouncil. Ca/ English/index.

Hartman, M.1996.Growing Flax:Diseases. The Flax Council of Canada.

Krylova,T.V.1981.Rhizoctoniosis of fiber flax. Mikologiya Fitopatologiya 15:511-513

Ligocka A.,Z.Paluszak,S.Sadowski,and T.Dziedzic.2002. Enzymatic and antagonist potential observed in flaxroot-infecting fungi.Electronic Journal of polish Agricultural Universities, Agronmy 5(1).Available Online http://WWW.ejpau.media.pl.
Van Bruggen,A.H.C.,N.J.Gmnwald, and M.Bolda.1996. Cultural methods and soil nutrient status in low and high input agricultural systems, as they affect Rhizoctonia species. In: Rhizoctonia species: Taxonomy, Molecular Biology, Ecology, Pathology, and Disease Control. (eds B. Sneh, S. Jabaji- here, S. Neate, and G.Dijst. Kluwer Acade Publishers ,Dordrech, The Netherland.407-421.

Wattkins, G. M. ed. 1981. Compendium of Cotton Diseases. The American Phytopathological Society.St.Paul., Minnesota,87p.

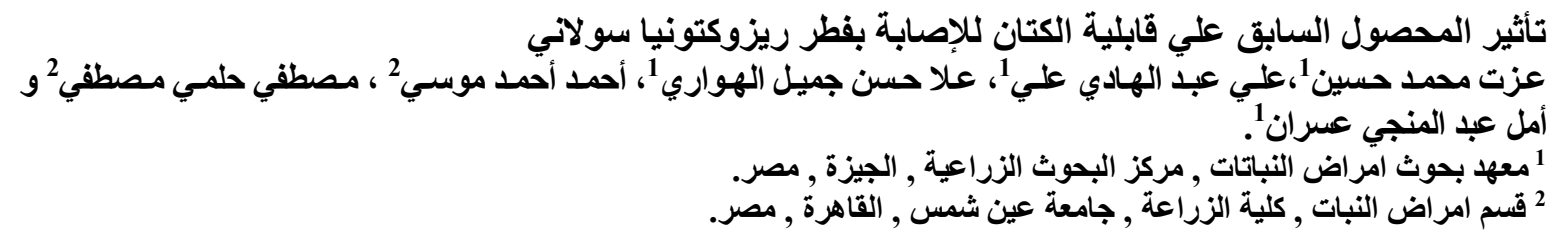

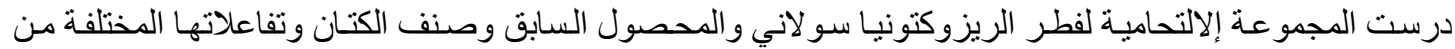

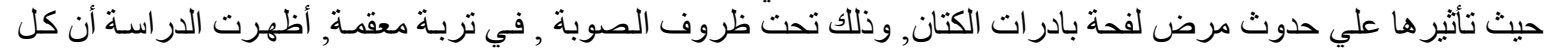

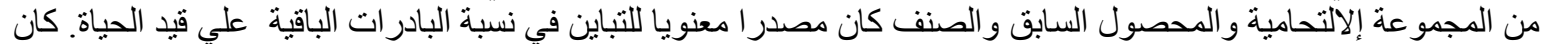

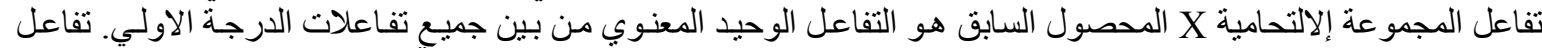
الدرجة الثانية للمجمو عة إلالتحامية X المحصول السابق X الصنف كان مصدرا غير معنويا". للتباين. جميع المحاصيل السابقة

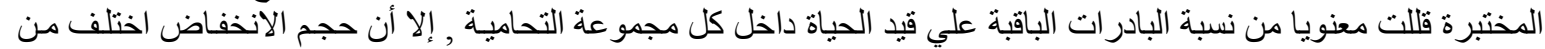

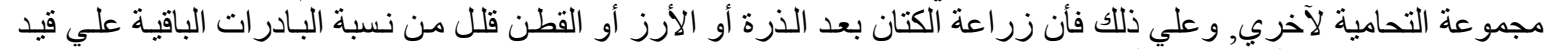

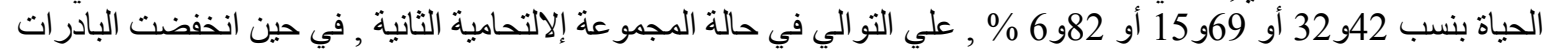

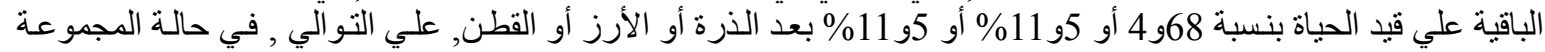
إلالتحامبة الرابعة فئة 